\title{
Relationship between Phloem Fiber and Trailing Habit, and Independent Inheritance of Growth Habit and Flower Form in Periwinkle
}

\author{
Huan-Keng Lin ${ }^{1}$ and Tzu-Yao Wei \\ Department of Horticulture and Landscape Architecture, National Taiwan University, Taipei, Taiwan \\ Chin-Mu Chen \\ Department of Horticulture, National Chung Hsing University, Taichung, Taiwan \\ Der-Ming Yeh ${ }^{2}$ \\ Department of Horticulture and Landscape Architecture, National Taiwan University, Taipei, Taiwan
}

\begin{abstract}
AdDitional INDEX words. bedding plant, Catharanthus roseus, double flower, modulus of elasticity, stem anatomy, vinca
AвSTRACт. Stem anatomy and modulus of elasticity (MOE) were compared between upright and trailing cultivars of periwinkle [Catharanthus roseus (G.) Don.]. The inheritance of growth habit and flower form was also studied. Internode cross sections revealed that phloem fiber was distributed at the inner cortex in upright cultivars but not in trailing cultivars. Except the youngest internode, the upright 'Vitesse Pink' had the highest MOE throughout the 1st13th internodes above the cotyledon. The more trailing 'Cora Cascade Strawberry' had consistently lower MOE than a less trailing 'Cora Cascade Polka Dot'. All $F_{1}$ plants between upright and trailing cultivars were upright, and the $F_{2}$ generation derived from self-pollinating $F_{1}$ fit a 3 upright : 1 trailing segregation ratio. All $F_{1}$ plants between upright/ double-flower and trailing/single-flower exhibited upright and single-flowers, whereas plants in the $F_{2}$ generation fitted a 9 upright/single-flower : 3 trailing/single-flower : 3 upright/double-flower : 1 trailing/double-flower ratio. New doubleflowered periwinkle selections with trailing growth habit were successfully developed from the $F_{2}$ population.
\end{abstract}

Periwinkle, a member of the Apocynaceae family, has longlasting flowering periods under warm climates, with many flower color variations. Periwinkle has become an important bedding plant or potted flowering plant in the world owing to its tolerance to heat and drought, and well adaptation (Curry, 2012). Periwinkle is also known for its use of terpenoid indole alkaloids for treating cardiac diseases and certain tumors in mammals (Zhou et al., 2009).

Most periwinkle cultivars have an upright growth habit, although trailing cultivars are desirable as they have increased their utility as ornamental plants for uses in hanging baskets and mixed containers, and as groundcover in the landscape. Trailing habits can be related to less or gradual loss of fiber tissue within stems (Evert, 2006). Fibers provide much of the mechanical support; therefore, subshrubs are expected to have a higher portion of fibers than climbers (Crivellaro et al., 2012). In nonself-supporting Clematis vitalba L. and Clematis maritima L., primary phloem fiber and collenchyma are displaced outward by plant development, which led to disrupting the mechanical integrity, but not in semiself-supporting Clematis recta L. (Rowe et al., 2004).

Modulus of elasticity measures the resistance of an object or substance to being deformed elastically when a mechanical force is applied to it. Biomechanical properties, such as stem

Received for publication 2 Nov. 2017. Accepted for publication 29 Dec. 2017. This article is a portion of a thesis submitted by Huan-Keng Lin.

We gratefully acknowledge the financial support from the Ministry of Science and Technology, Taiwan, Republic of China.

${ }^{1}$ Deceased.

${ }^{2}$ Corresponding author. E-mail: dmyeh@ntu.edu.tw. stiffness or elasticity can be quantitatively compared with MOE (Niklas, 1995). MOE decreased significantly after loss of fibers in $C$. vitalba and C. maritima, but not in C. recta, which remained higher MOE (Rowe et al., 2004). Stems of upright periwinkle contained phloem fiber (Kartmazova, 1972), but no information is available on stem anatomy or MOE of trailing cultivars.

Genetic control of growth habit varies among plant species. For example, growth habit of cowpea [Vigna unguiculata (L.) Walp.] is governed by two allelic pairs, $A A$ and $B B$. The genotype $A_{-} B_{-}$has the prostrate growth habit; the genotype $a a B_{\text {_ }}$ has the climbing growth habit, and $a a b b$ has the bushy habit (Uguru and Uzo, 1991). In red clover (Trifolium pretense L.), a dominance $\times$ dominance epistasis controls prostrateness, with prostrate being partially dominant to erect (MirzaieNodoushan et al., 1999). Egyptian clover (Trifolium alexandrinum L.) is erect, whereas Trifolium apertum Bobrov is prostrate, and all their $F_{1}$ plants were erect, indicating thereby dominance of erect habit over the prostrate (Malaviya et al., 2004). Growth habit of coleus [Solenostemon scutellarioides (L.) Codd] is controlled by a single gene $(U)$ with additive effects, and upright is dominant to trailing. Upright growth habit is designated with a UUUU genotype and trailing with a ииии genotype (Nguyen et al., 2008). Information on the genetics for the trailing growth habit of periwinkle is presently limited.

Flower doubleness generally increases the ornamental value of floriculture crops. We have released double-flowered periwinkle cultivars (Chen and Yeh, 2012) and proposed that a nuclear recessive gene controls the double-flowering phenotype, and the dominant allele conditions single flowers in either the homozygous or heterozygous state (Chen et al., 2012). 
Presently, there appears no double-flowered periwinkle cultivar with a trailing growth habit.

The objectives of this study were to 1) compare the stem anatomy and MOE between upright and trailing cultivars, 2) determine the genetics and inheritance of trailing habit and flower form, and 3) develop new periwinkle progeny with trailing habit and double flowers.

\section{Materials and Methods}

All the plants were raised from seeds, and young plants were transplanted into 9-cm pots containing 2 peatmoss (Fafard No. 1; Conrad Fafard, Agawarm, MA) : 1 vermiculite : 1 perlite (by volume). The plants were placed in a greenhouse with day/night temperatures of $32 / 25^{\circ} \mathrm{C}$ under $11.1-13.2 \mathrm{~h}$ daylengths, with an average noontime photosynthetic photon flux of $1382 \mu \mathrm{mol} \cdot \mathrm{m}^{-2} \cdot \mathrm{s}^{-1}$. Plants were fertilized with water-soluble $20 \mathrm{~N}-8.7 \mathrm{P}-16.6 \mathrm{~K}$ (20-20-20 General Purpose; JR Peters, Allentown, PA) at $1 \mathrm{~g} \cdot \mathrm{L}^{-1}$ and irrigated as needed.

Stem anatomy and MOE Between UPRIGHT AND TRAILING CULTIVARS. Stem anatomy study was conducted between the upright cultivar Vitesse Pink and trailing cultivar Cora Cascade Polka Dot when the plants had two flowers. The lowest internode of the main stem was cross-sectioned by hand and stained with $0.5 \%$ safranin O (Sigma-Aldrich, St Louis, MO) and $1 \%$ alcian blue (in $3 \%$ acetic acid; Sigma-Aldrich). Stem tissues were observed with a light microscope (Eclipse E600; Nikon, Tokyo, Japan). In addition, stem segments of upright 'Vitesse Pink' were immersed in $\mathrm{H}_{2} \mathrm{O}_{2}$ solution $\left(30 \% \mathrm{H}_{2} \mathrm{O}_{2}\right.$ : distilled water : glacial acetate $=1: 4: 5$ ) at $60{ }^{\circ} \mathrm{C}$ for $3 \mathrm{~d}$. Then, rinsed with distilled water thoroughly and stained with $1 \%$ safranin $O$ (in 50\% ethanol). After rinsing, the sample was examined under a microscope for compositions of tissues.

Apart from 'Vitesse Pink' and 'Cora Cascade Polka Dot', a more trailing cultivar Cora Cascade Strawberry was added for the comparison of their stem tissues and MOE. The 1st, 5th, 8th, 11 th, and 13 th (the youngest) internodes above cotyledons were sectioned. Proportions of cortex, phloem fiber, phloem, xylem, and pith area were analyzed by ImageJ (National Institutes of Health, Bethesda, MD) after taking microscopic photos (Optronics Microfire True Color Firewire Digital CCD; Meyer Instruments, Houston, TX). MOE was measured after the process described by Jacobsen et al. (2005). Plants were watered thoroughly at the day before MOE test and sealed in plastic bags to prevent water evaporation. Stem segments were cut and the test was conducted within $20 \mathrm{~min}$. A four-point bending test was conducted under $25^{\circ} \mathrm{C}$ using a microtester (Microtest M200; Deben, East Grinstead, UK).

The experiment was arranged in a completely randomized design and replicated three times with three-to-five stem samples per replication for each cultivar. Least significant differences were determined at $P<0.05$ to compare among the means. The relationship between proportions of various tissue areas and internode position was determined by using regression analysis using SigmaPlot (version 10.0; Systat Software, San Jose, CA). The relationship between proportions of various tissue areas and MOE was determined with correlation analysis.

INHERITANCE OF TRAILING HABIT AND FLOWER FORM. Upright, double-flowered cultivars Taoyuan No. 1-Rose Girl, Taoyuan No. 4-Summer Snow, and Taoyuan No. 5-Red Lady and trailing, single-flowered cultivars Cora Cascade Strawberry, Cora Cascade Polka Dot, and Cora Cascade Magenta were

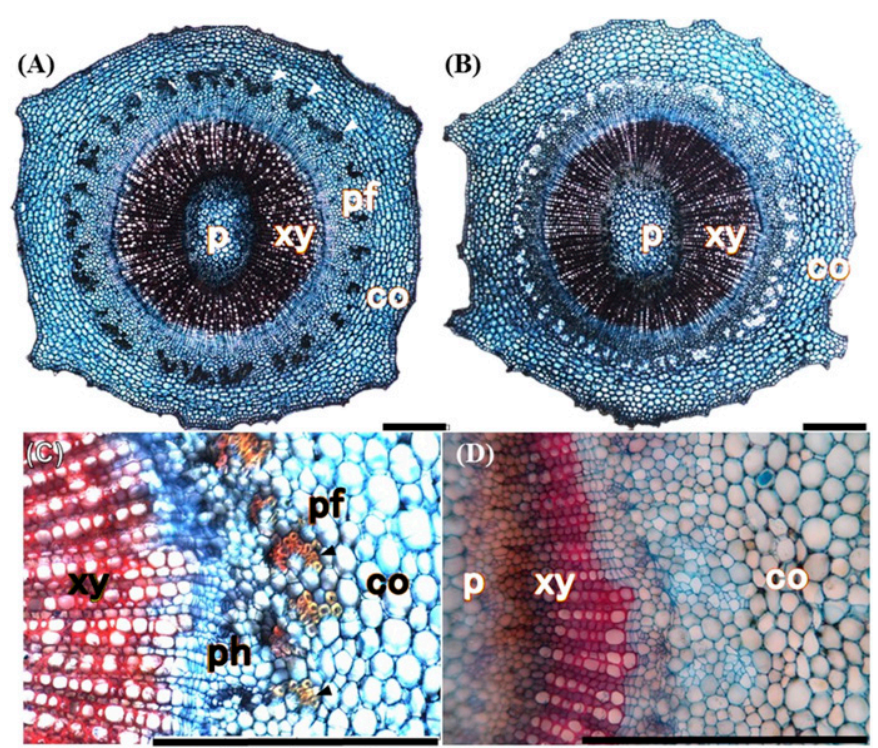

Fig. 1. Stem internode cross sections stained with safranin $\mathrm{O}$ and alcian blue of upright periwinkle 'Vitesse Pink' (A and $\mathbf{C}$ ) and trailing periwinkle 'Cora Cascade Polka Dot' $(\mathbf{B}$ and $\mathbf{D})$; co = cortex; $\mathrm{pf}=$ phloem fiber; $\mathrm{ph}=$ phloem; $\mathrm{xy}=\mathrm{xylem} ; \mathrm{p}=$ pith; arrowheads indicate phloem fiber; bars $=500 \mu \mathrm{m}$.

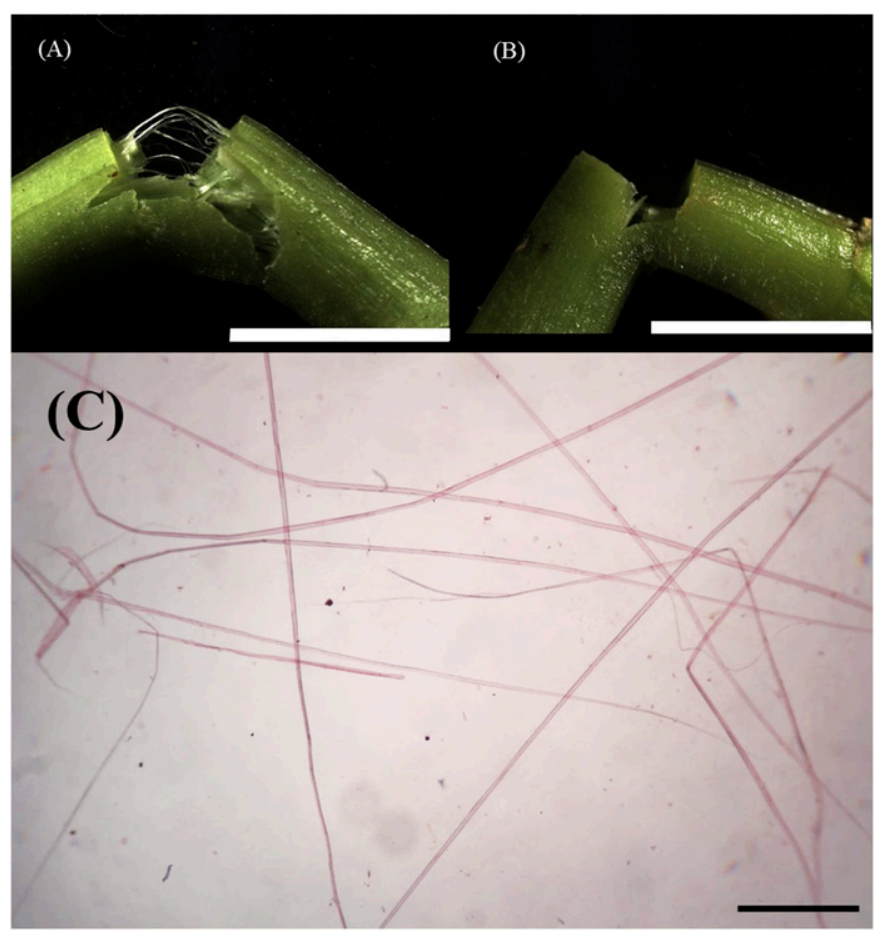

Fig. 2. Stem fragment of upright periwinkle 'Vitesse Pink' (A) and trailing periwinkle 'Cora Cascade Polka Dot' $(\mathbf{B})$, and macerated fiber of upright periwinkle 'Vitesse Pink' $(\mathbf{C})$; bar $=1 \mathrm{~cm}(\mathbf{A}$ and $\mathbf{B})$; bar $=500 \mu \mathrm{m}(\mathbf{C})$.

self-pollinated and cross-pollinated. Because periwinkle is a self-pollinating species, we performed emasculation and cross-pollination following the method described by Miyajima (2004). $F_{1}, F_{2}$, and backcross family were produced. Plants were raised as described earlier. Growth habit and flower form were recorded when the plants had two open flowers, following the International Union for the Protection of New Varieties of Plants guidelines. Data were subjected to 
Table 1. Proportion of tissue structure and modulus of elasticity (MOE) of different internode positions in periwinkle cultivars Vitesse Pink (VP), Cora Cascade Polka Dot (CCP), and Cora Cascade Strawberry (CCS).

\begin{tabular}{|c|c|c|c|c|c|c|}
\hline Internode position and cultivar ${ }^{z}$ & Cortex area $(\%)$ & Phloem fiber area (\%) & Phloem area $(\%)$ & Xylem area $(\%)$ & Pith area $(\%)$ & $\operatorname{MOE}\left(\mathrm{N} \cdot \mathrm{mm}^{-2}\right)$ \\
\hline \multicolumn{7}{|l|}{1} \\
\hline $\mathrm{CCP}$ & $35.5 \mathrm{a}$ & $0.0 \mathrm{~b}$ & $28.8 \mathrm{~b}$ & $33.3 \mathrm{a}$ & $2.4 \mathrm{~b}$ & $244.96 \mathrm{a}$ \\
\hline \multicolumn{7}{|l|}{5} \\
\hline VP & $41.9 \mathrm{~b}$ & $5.5 \mathrm{a}$ & $21.6 \mathrm{c}$ & $17.1 \mathrm{~b}$ & $13.8 \mathrm{a}$ & $145.77 \mathrm{a}$ \\
\hline $\mathrm{CCP}$ & $45.3 \mathrm{a}$ & $0.0 \mathrm{~b}$ & $24.2 \mathrm{~b}$ & $19.6 \mathrm{a}$ & $11.0 \mathrm{~b}$ & $124.65 \mathrm{~b}$ \\
\hline \multicolumn{7}{|l|}{8} \\
\hline VP & $45.5 \mathrm{a}$ & $4.1 \mathrm{a}$ & $20.3 \mathrm{a}$ & $13.9 \mathrm{a}$ & $16.2 \mathrm{a}$ & $105.93 \mathrm{a}$ \\
\hline $\mathrm{CCP}$ & $45.9 \mathrm{a}$ & $0.0 \mathrm{~b}$ & $22.0 \mathrm{a}$ & $16.2 \mathrm{a}$ & $15.9 \mathrm{a}$ & $89.36 \mathrm{a}$ \\
\hline CCS & $48.9 \mathrm{a}$ & $0.0 \mathrm{~b}$ & $22.2 \mathrm{a}$ & $13.5 \mathrm{a}$ & $15.4 \mathrm{a}$ & $50.90 \mathrm{~b}$ \\
\hline \multicolumn{7}{|l|}{11} \\
\hline VP & $48.9 \mathrm{a}$ & $2.8 \mathrm{a}$ & $18.9 \mathrm{a}$ & $10.8 \mathrm{a}$ & $19.5 \mathrm{a}$ & $65.58 \mathrm{a}$ \\
\hline $\mathrm{CCP}$ & $50.7 \mathrm{a}$ & $0.0 \mathrm{~b}$ & $17.8 \mathrm{a}$ & $8.5 \mathrm{a}$ & $23.0 \mathrm{a}$ & $25.61 \mathrm{a}$ \\
\hline CCS & $52.3 \mathrm{a}$ & $0.0 \mathrm{~b}$ & $18.1 \mathrm{a}$ & $8.3 \mathrm{a}$ & $21.4 \mathrm{a}$ & $18.93 \mathrm{a}$ \\
\hline \multicolumn{7}{|l|}{ Significance } \\
\hline Internode position & $\mathrm{L} * * *$ & NS & $\mathrm{L}^{* * *} \mathrm{Q}^{*}$ & $\mathrm{~L}^{* * *} \mathrm{Q} * *$ & $\mathrm{~L}^{* * *} \mathrm{Q}^{*}$ & $\mathrm{~L} * * *$ \\
\hline
\end{tabular}

${ }_{\mathrm{z}}$ Internode position from the base, as counted above the cotyledon.

${ }^{\mathrm{y}}$ Means within columns followed by different letters per internode position are significantly different $(P<0.05)$ based on Fisher's protected least significant difference.

Ns, *,**, ${ }^{* * *}$ Nonsignificant or significant at $P<0.05,0.01$, or 0.001 , respectively; $\mathrm{L}=$ linear; $\mathrm{Q}=$ quadratic.

Table 2. Correlation coefficient between modulus of elasticity and tissue area proportion of different internodal positions in periwinkle cultivars Vitesse Pink, Cora Cascade Polka Dot, and Cora Cascade Strawberry.

\begin{tabular}{lccccc}
\hline & \multicolumn{5}{c}{ Correlation coefficient } \\
\cline { 2 - 6 } Internode position $^{\mathrm{z}}$ & Cortex area & Phloem fiber area & Phloem area & Xylem area & Pith area \\
\hline 1 & $-0.71^{*}$ & 0.55 & 0.08 & $0.79^{*}$ & $-0.72^{*}$ \\
5 & -0.08 & $0.70^{*}$ & -0.57 & 0.34 & -0.31 \\
8 & $-0.70^{*}$ & $0.70^{*}$ & -0.06 & 0.40 & 0.17 \\
11 & -0.58 & $0.76^{*}$ & 0.12 & 0.44 & -0.13 \\
13 & $-0.77^{*}$ & $0.67^{*}$ & 0.53 & 0.14 & 0.10 \\
\hline
\end{tabular}

${ }_{\mathrm{z}}$ Internode position from the base, as counted above the cotyledon.

* Significance at $P<0.05$ level based on the table of critical values for Pearson's correlation coefficients $(r)$ with $\mathrm{df}=14$.

Table 3. Phenotype of six periwinkle cultivars used as parents for crosses in this study and their self-pollinated progenies.

\begin{tabular}{lll}
\hline Cultivar (abbreviation) & Growth habit & Flower form \\
\hline Taoyuan No. 1-Rose Girl (TY1) & Upright & Double \\
Taoyuan No. 4-Summer Snow (TY4) & Upright & Double \\
Taoyuan No. 5-Red Lady (TY5) & Upright & Double \\
Cora Cascade Polka Dot (CCP) & Trailing & Single \\
Cora Cascade Strawberry (CCS) & Trailing & Single \\
Cora Cascade Magenta (CCM) & Trailing & Single \\
TY1 $\otimes^{z}$ & Upright & Double \\
TY4 $\otimes$ & Upright & Double \\
TY5 $\otimes$ & Upright & Double \\
CCP $\otimes$ & Trailing & Single \\
CCS $\otimes$ & Trailing & Single \\
CCM $\otimes$ & Trailing & Single \\
\hline
\end{tabular}

${ }^{\mathrm{z}}$ Thirty progenies were examined. chi-square test for goodness of fit to compare actual ratios with expected ratio.

\section{Results and Discussion}

STEM ANATOMY AND MOE BETWEEN UPRIGHT AND TRAILING CULTIVARS. Internode cross sections of the upright 'Vitesse Pink' revealed that phloem fiber was distributed right next to cortex cells, but not in the trailing 'Cora Cascade Polka Dot' (Fig. 1A-D). Hand-broken stem segments and macerated stem segments showed the existence of phloem fiber in 'Vitesse Pink' (Fig. 2A and C) but not in 'Cora Cascade Polka Dot' (Fig. 2B). Kartmazova (1972) also showed the existence of stem phloem fiber in upright periwinkle. We dissected the stem and observed the phloem fiber in four other upright cultivars (including the Taoyuan series and Jams 'N Jellies Blackberry) but not in 18 other trailing cultivars (including the Cora Cascade, Mediterranean, and Boa series) in another experiment (data not shown). Results indicate that phloem fiber affects the growth habit of periwinkle in that trailing cultivars lack phloem fiber. Gorshkova et al. (2012) have demonstrated that fibers are important in establishing plant architecture, as a source of mechanical support. Wang and Gregg (1989) reported that 'Jane Cowl' hibiscus (Hibiscus L.) produced trailing, instead of upright, shoots after the treatment with uniconazole because of the decreased cell size and cell wall thickness, as well as the greatly diminished phloem fiber and fibers that are hollow. 
Table 4. Segregation for upright and trailing growth habit in progeny of 21 periwinkle crosses.

\begin{tabular}{|c|c|c|c|c|c|}
\hline \multirow[b]{2}{*}{ Crosses (cross no.) ${ }^{\mathrm{z}}$} & \multicolumn{2}{|c|}{ Growth habit } & \multirow[b]{2}{*}{ Test ratio } & \multirow[b]{2}{*}{$\chi^{2}$} & \multirow[b]{2}{*}{$P$} \\
\hline & Upright & Trailing & & & \\
\hline \multicolumn{6}{|l|}{$\overline{\mathrm{F}_{1}}$} \\
\hline $\mathrm{TY} 1 \times \mathrm{CCS}(1)$ & 12 & 0 & $1: 0$ & 0 & 1 \\
\hline $\mathrm{TY} 4 \times \mathrm{CCP}(2)$ & 23 & 0 & $1: 0$ & 0 & 1 \\
\hline TY 5 × CCM (3) & 14 & 0 & $1: 0$ & 0 & 1 \\
\hline $\mathrm{CCM} \times \mathrm{TY} 1(4)$ & 31 & 0 & $1: 0$ & 0 & 1 \\
\hline $\mathrm{CCM} \times \mathrm{TY} 5(5)$ & 13 & 0 & $1: 0$ & 0 & 1 \\
\hline $\mathrm{CCP} \times \mathrm{TY} 1(6)$ & 18 & 0 & $1: 0$ & 0 & 1 \\
\hline $\mathrm{CCP} \times \mathrm{TY} 5(7)$ & 38 & 0 & $1: 0$ & 0 & 1 \\
\hline $\mathrm{CCS} \times \mathrm{TY} 1(8)$ & 77 & 0 & $1: 0$ & 0 & 1 \\
\hline $\mathrm{CCS} \times \mathrm{TY} 5(9)$ & 13 & 0 & $1: 0$ & 0 & 1 \\
\hline \multicolumn{6}{|l|}{$\mathrm{F}_{2}$} \\
\hline $\mathrm{TY} 1 \times \mathrm{CCS} \mathrm{F}_{1}-1^{\mathrm{y}} \otimes(10)$ & 23 & 5 & $3: 1$ & 0.76 & 0.38 \\
\hline $\mathrm{TY} 4 \times \mathrm{CCP} \mathrm{F}_{1}-2 \otimes(11)$ & 40 & 12 & $3: 1$ & 0.10 & 0.75 \\
\hline $\mathrm{TY} 4 \times \mathrm{CCP} \mathrm{F}_{1}-4 \otimes(12)$ & 28 & 5 & $3: 1$ & 1.71 & 0.19 \\
\hline $\mathrm{TY} 4 \times \mathrm{CCP} \mathrm{F}_{1}-6 \otimes(13)$ & 51 & 10 & $3: 1$ & 2.41 & 0.12 \\
\hline $\mathrm{TY} 4 \times \mathrm{CCP} \mathrm{F}_{1}-15 \otimes(14)$ & 52 & 17 & $3: 1$ & 0 & 0.94 \\
\hline $\mathrm{TY} 5 \times \mathrm{CCM} \mathrm{F}_{1}-1 \otimes(15)$ & 138 & 45 & $3: 1$ & 0.02 & 0.90 \\
\hline $\mathrm{TY} 5 \times \mathrm{CCM} \mathrm{F}_{1}-2 \otimes(16)$ & 93 & 21 & $3: 1$ & 2.63 & 0.10 \\
\hline $\mathrm{TY} 5 \times \mathrm{CCM} \mathrm{F}_{1}-3 \otimes(17)$ & 152 & 57 & $3: 1$ & 0.58 & 0.45 \\
\hline $\mathrm{TY} 5 \times \mathrm{CCM} \mathrm{F}_{1}-9 \otimes(18)$ & 243 & 99 & $3: 1$ & 2.84 & 0.09 \\
\hline $\mathrm{CCP} \times \mathrm{TY} 1 \mathrm{~F}_{1}-3 \otimes(19)$ & 31 & 5 & $3: 1$ & 2.37 & 0.12 \\
\hline $\mathrm{CCP} \times \mathrm{TY} 5 \mathrm{~F}_{1}-24 \otimes(20)$ & 71 & 28 & $3: 1$ & 0.57 & 0.45 \\
\hline $\mathrm{CCP} \times \mathrm{TY} 5 \mathrm{~F}_{1}-31 \otimes(21)$ & 136 & 33 & $3: 1$ & 2.70 & 0.10 \\
\hline
\end{tabular}

${ }^{\mathrm{z} T Y 1}=$ Taoyuan No. 1-Rose Girl; TY4 = Taoyuan No. 4-Summer Snow; TY5 = Taoyuan No. 5-Red Lady; CCP = Cora Cascade Polka Dot; $\mathrm{CCS}=$ Cora Cascade Strawberry; CCM = Cora Cascade Magenta. ${ }^{\mathrm{y}}$ Code number of selected progeny.
Phloem fibers were observed in the upright 'Vitesse Pink' throughout the internodes sampled, but not in the trailing 'Cora Cascade Polka Dot' and 'Cora Cascade Strawberry' (Table 1). Trailing periwinkle cultivars lack stem phloem fiber, regardless of internode position. This differs to prostrate $C$. vitalba and $C$. maritima that phloem fibers are displaced outward as by plant development, which led to disrupted mechanical integrity (Rowe et al., 2004).

Regardless of cultivars, the basal internodes had lower proportions of cortex and pith but higher proportions of phloem and xylem, and MOE (Table 1). Rowe et al. (2004) also reported that biomechanical properties of the plant stem can change markedly during growth where young apical parts are relatively compliant and the basal and older stages are relatively stiff.

Except that MOE of the youngest internode did not differ among the cultivars; the upright Vitesse Pink had the highest MOE (Table 1). Our results are consistent with previous reports that mechanical properties of the upright stems are stiffer than horizontal axes in terms of both flexural stiffness and structural Young's modulus (Rowe and Speck, 1998).

Except for the youngest internode, anatomical observation and correlation analysis showed that 'Cora Cascade Strawberry' had consistently lower MOE and proportion of basal xylem area than 'Cora Cascade Polka Dot' (Tables 1 and 2). This may explain why 'Cora Cascade Strawberry' exhibits a more trailing growth habit than 'Cora Cascade Polka Dot'. Rowe et al. (2004) showed sclerenchyma area correlates well with the changes in MOE; i.e., stem stiffness or elasticity for other plants. Results in this study show that phloem fiber appeared in the upright periwinkle cultivars but not in trailing cultivars, whereas xylem is crucial in determining mechanical strength in trailing cultivars.

INHERITANCE OF UPRIGHT AND TRAILING GROWTH HABITS. Three upright/double-flowered cultivars (Taoyuan No. 1-Rose Girl, Taoyuan No. 4-Summer Snow, and Taoyuan No. 5-Red Lady) and three trailing/single-flowered cultivars (Cora Cascade Strawberry, Cora Cascade Polka Dot, and Cora Cascade Magenta) were used as parents. Progeny from self-pollination of these cultivars exhibited the same phenotype as their parents (Table 3), indicating the homozygosity status of their growth habit and flower form.

All $F_{1}$ plants of upright $\times$ trailing (cross no. 1-3) and trailing $\times$ upright crosses (cross no. 4-9), including reciprocal crosses between 'Taoyuan No. 1-Rose Girl' and 'Cora Cascade Strawberry', 'Taoyuan No. 5-Red Lady' and 'Cora Cascade Magenta' were upright (Table 4). The $\mathrm{F}_{2}$ generation derived from self-pollinating $\mathrm{F}_{1}$ (cross no. 10-21) fit a 3 upright : 1 trailing segregation ratio $\left(\chi^{2}=0\right.$ 2.84, $P=0.09-0.94)$. These results indicate that growth habit seems to be controlled by one single nuclear locus with two alleles and that upright allele was dominant over the trailing allele. Similar examples for 


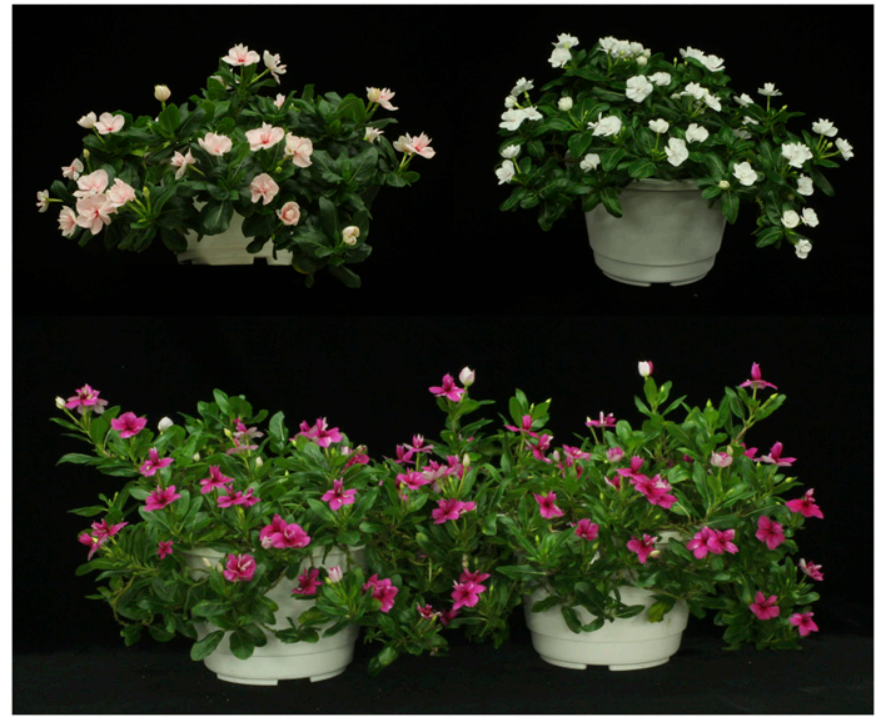

Fig. 3. Several trailing double-flowered periwinkles selected in this study.

recessive gene(s) conditioning trailing habit have been reported in coleus (Nguyen et al., 2008) and red clover (MirzaieNodoushan et al., 1999).

INDEPENDENT INHERITANCE BETWEEN GROWTH HABIT AND FLOWER FORM. All $\mathrm{F}_{1}$ plants of upright/double-flower $\times$ trailing/single-flower (cross no. 22-24) and trailing/single-flower $\times$ upright/double-flower (cross no. 25) crosses exhibited upright growth habit and produced single flowers (Table 5). Results are consistent with Table 4 that upright is dominant over trailing and support the previous observation that single-flower is dominant over double-flower (Chen et al., 2012).

The $\mathrm{F}_{2}$ progeny from self-pollinating $\mathrm{F}_{1}$ plants (cross no. 26 32) exhibited four phenotypic types (Table 5), indicating that the $F_{1}$ plants were heterozygous for growth habit and flower form. Plants in the $\mathrm{F}_{2}$ generation fitted a 9 upright/single-flower : 3 trailing/single-flower : 3 upright/double-flower : 1 trailing/doubleflower ratio $\left(\chi^{2}=0.50-7.40, P=0.06-0.92\right)$. The observed ratio supports that two independent loci control the two traits of growth habit and flower form. Backcrosses of the $F_{2}$ plants to upright, double-flowered parents (cross no. 33, 35) resulted in all upright plants but were segregated into 1 single : 1 double-flowered progeny $\left(\chi^{2}=0.15-2.92, P=0.08-0.69\right)$. Backcrosses with trailing, single-flowered parents (cross no. 34,36 ) produced all single-flowered progeny, but were segregated into 1 upright : 1 trailing ratio $\left(\chi^{2}=0-0.12, P=0.73-1\right)$. Segregation data obtained from $\mathrm{F}_{1}, \mathrm{~F}_{2}$, and backcross families (Table 5) confirm previous observations (Chen et al., 2012) that the double-flowered phenotype is controlled by a recessive allele in periwinkle. Similar examples for a monogenic recessive gene conditioning flower doubling have been reported in Nicotiana alata Link \& Otto (Zainol and Stimart, 2001) and Papaver somniferum L. (Dhawan et al., 2007). Previous reports showed that young seedlings of upright/double-flowered progeny had distorted leaves before the sixth pair of leaves emerged in periwinkle (Chen and Yeh, 2012; Chen et al., 2012). In this study, regardless of the trailing or upright habit, double-floweredness allele was also linked to the leaf distortion allele as reported previously.

New double-flowered periwinkle selections with trailing growth habit were successfully developed from the $\mathrm{F}_{2}$ population [Fig. 3; Table 5 (cross no. 26-32)]. Trailing periwinkle cultivars are characterized by having a prostrate or trailing branching pattern, without stem phloem fiber. We consider both the lack of phloem fiber and leaf distortion to be measures for early selection of trailing and double-flowered periwinkles, respectively.

\section{Literature Cited}

Chen, C.M., T.Y. Wei, and D.M. Yeh. 2012. Morphology and inheritance of double floweredness in Cathranthus roseus. HortScience 47:1679-1681.

Chen, C.M. and D.M. Yeh. 2012. 'Taoyuan No. 1-Rose Girl': A double-flowered periwinkle, Catharanthus roseus. HortScience 47:1175-1176.

Crivellaro, A., K. McCulloh, F.A. Jones, and B. Lachenbruch. 2012. Anatomy and mechanical and hydraulic needs of woody climbers contrasted with subshrubs on the island of Cyprus. IAWA J. 33:355-373.

Curry, H.A. 2012. Naturalising the exotic and exoticising the naturalised: Horticulture, natural history and the rosy periwinkle. Environ. Hist. 18:343-365.

Dhawan, O.P., M.K. Dubey, and S.P.S. Khanuja. 2007. Detection of a true breeding homeotic gene mutant Pps-1 with partially petaloid sepals in opium poppy (Papaver somniferum L.) and its genetic behavior. J. Hered. 98:373-377.

Evert, R.F. 2006. Esau's plant anatomy. 3rd ed. Wiley, New York, NY. Gorshkova, T., N. Brutch, B. Chabbert, M. Deyholos, T. Hayashi, S.L. Yadun, E.J. Mellerowicz, C. Morvan, G. Neutelings, and G. Pilate. 2012. Plant fiber formation: State of the art, recent and expected progress, and open questions. Crit. Rev. Plant Sci. 31:201-228.

Jacobsen, A.L., F.W. Ewers, R.B. Pratt, W.A. Paddock, III, and S.D. Davis. 2005. Do xylem fibers affect vessel cavitation resistance? Plant Physiol. 139:546-556.

Kartmazova, L.S. 1972. Anatomical investigations on Catharanthus roseus. Part 1: The structure of the vegetative organs. Rastitel'nye Resursy 8:263-274.

Malaviya, D.R., A.K. Roy, P. Kaushal, B. Kumar, and A. Tiwari. 2004. Development and characterization of interspecific hybrids of Trifolium alexandrinum $\times T$. apertum using embryo rescue. Plant Breeding 123:536-542.

Mirzaie-Nodoushan, H., I.L. Gordon, and W.B. Rumball. 1999. Inheritance of growth habit-related attributes in red clover (Trifolium pratense L.). J. Hered. 90:550-553.

Miyajima, D. 2004. Pollination and seed set in vinca [Catharanthus roseus (L.) G. Don]. J. Hort. Sci. Biotechnol. 79:771-775.

Nguyen, P., K. Quesenberry, and D. Clark. 2008. Genetics of growth habit and development of new coleus [Solenostemon scutellarioides (L.) Codd] varieties with trailing habit and bright color. J. Hered. 99:573-580.

Niklas, K.J. 1995. Plant height and the properties of some herbaceous stems. Ann. Bot. 75:133-142.

Rowe, N., S. Isnard, and T. Speck. 2004. Diversity of mechanical architectures in climbing plants: An evolutionary perspective. J. Plant Growth Regulat. 23:108-128.

Rowe, N.P. and T. Speck. 1998. Biomechanics of plant growth forms: The trouble with fossil plants. Rev. Palaeobot. Palynol. 102:43-62.

Uguru, M.I. and J.O. Uzo. 1991. Segregation pattern of decumbent, climbing and bushy growth habits in Vigna unguiculata (L.) Walp. Plant Breeding 107:173-176.

Wang, Y.T. and L.L. Gregg. 1989. Uniconazole affects vegetative growth, flowering, and stem anatomy of hibiscus. J. Amer. Soc. Hort. Sci. 114:927-932.

Zainol, R. and D.P. Stimart. 2001. A monogenic recessive gene, $f w$, conditions flower doubling in Nicotiana alata. HortScience 36:128-130.

Zhou, M.L., J.R. Shao, and Y.X. Tang. 2009. Production and metabolic engineering of terpenoid indole alkaloids in cell cultures of the medicinal plant Catharanthus G. Don (Madagascar periwinkle). Biotechnol. Appl. Biochem. 52:313-323. 